\title{
The Buffering Hypothesis: Growing Diversity and Declining Black-White Segregation in America's Cities, Suburbs, and Small Towns?
}

\author{
Domenico Parisi, ${ }^{a}$ Daniel T. Lichter, ${ }^{b}$ Michael C. Taquino ${ }^{a}$
}

a) Mississippi State University; b) Cornell University

Abstract: The conventional wisdom is that racial diversity promotes positive race relations and reduces racial residential segregation between blacks and whites. We use data from the 1990-2010 decennial censuses and 2007-2011 ACS to test this so-called "buffering hypothesis." We identify cities, suburbs, and small towns that are virtually all white, all black, all Asian, all Hispanic, and everything in between. The results show that the most racially diverse places-those with all four racial groups (white, black, Hispanic, and Asian) present-had the lowest black-white levels of segregation in 2010. Black-white segregation also declined most rapidly in the most racially diverse places and in places that experienced the largest recent increases in diversity. Support for the buffering hypothesis, however, is counterbalanced by continuing high segregation across cities and communities and by rapid white depopulation in the most rapidly diversifying communities. We argue for a new, spatially inclusive perspective on racial residential segregation.

Keywords: diversity; segregation; entropy; community; urban, rural

Citation: Parisi, Domenico, Daniel T. Lichter and Michael C. Taquino. 2015. "The Buffering Hypothesis: Growing Diversity and Declining Black-White Segregation in America's Cities, Suburbs, and Small Towns?" Sociological Science 2: 125-157.

Received: December 2, 2014

Accepted: December 22, 2014

Published: March 25, 2015

Editor(s): Jesper Sørensen, Stephen Morgan

DOI: $10.15195 / \mathrm{v} 2 . \mathrm{a} 8$

Copyright: (C) 2015 The Author(s). This open-access article has been published under a Creative Commons Attribution License, which allows unrestricted use, distribution and reproduction, in any form, as long as the original author and source have been credited. (C) (i)
THE racial and ethnic composition of the U.S. population is being rapidly transformed by new immigration from Asia and Latin America (Lee and Bean 2010); high rates of fertility among Hispanics (Parrado 2011); and population aging, below-replacement fertility, and impending natural decrease among the United States' native-born white population (Johnson and Lichter 2008). Racial boundaries arguably have dimmed, if measured by changing racial attitudes, increasing interracial marriage rates, and declining racial residential segregation in the nation's largest cities. Yet any demographic dividend associated with growing diversity has been slow to arrive for African Americans. Racial boundaries often remain "bright" between black and other racial and ethnic populations, which raises the specter of continuing black exceptionalism (Parisi, Lichter, and Taquino 2011; Sears and Savalei 2006). In The Souls of Black Folk, W.E.B. Dubois (1997[1903]:45) famously stated that "the problem of the twentieth century is the problem of the color line," one that privileges whites over blacks. For African Americans, the problem of the color line has continued into the twenty-first century but expresses itself differently as the U.S. population has become more racially diverse.

We illustrate this point in our study. Specifically, we ask whether increasing U.S. diversity is associated with growth or decline in black-white residential segregation, a singular measure of changing racial boundaries and social distance. The optimistic view is that growing racial and ethnic diversity serves as a "buffer" between whites and blacks while diminishing the salience of race. The continuing growth of Hispanic and Asian populations presumably is reshaping the contours of racial 
and ethnic boundaries while promoting multiculturalism, mutual acceptance, and understanding. Racial distinctions matter less than they did in the past. Indeed, Alba (1999:20) claims that racial diversity and the emergence of multiculturalism "could dissolve the transparency of racial distinctions and thus impact upon the distinctions that set African Americans racially apart." Evidence for the so-called buffering hypothesis will be expressed locally in declining black-white residential segregation, especially in cities and communities undergoing rapid racial and ethnic change.

The pessimistic view, under the traditional assimilation model, is that Hispanics and Asians will increasingly distance themselves from African Americans. The argument here is that the making and remaking of ethnic and racial boundaries are rooted in continuing "black exceptionalism," a selective process of incorporation in which nonblack minorities distance themselves socially and physically from African Americans in order to gain access to and acceptance in mainstream U.S. society. With upward mobility, the United States' nonblack minorities presumably will shift along the racial continuum, toward whites and away from blacks. Some observers claim that the old white-nonwhite divide is rapidly being replaced by an emerging blacknonblack divide (Gans 1999; Lee and Bean 2010). As such, black exceptionalism presumably will be expressed in persistent or even growing black-white segregation in diversifying communities. Indeed, according to the place-stratification perspective, the aversion of whites-and nonblack minorities-to "sharing residential space with black neighbors" could reinforce racially segmented housing markets and discrimination (Crowder, Pais, and South 2012:328). Inter-neighborhood and inter-city patterns of geographic mobility among African Americans and whites may, on average, heighten rather than diminish spatio-racial boundaries.

This paper revisits the buffering hypothesis with three specific goals. First, we document unfolding patterns of racial diversity across all U.S. places—defined as big cities, suburbs, and rural communities-using newly concatenated data from the 1990, 2000, and 2010 decennial censuses. Our spatially inclusive, place-based perspective is unusual; it complements previous metro-centric research restricted to big city neighborhoods (e.g., census tracts) or to the largest or most diverse metropolitan areas. Our measurement framework accommodates small places by using blocks rather than census tracts as the basic accounting unit to estimate place-specific black-white segregation. Our approach resonates with new research calling for finer granularity in studying the spatial scale of segregation (Östh, Clark, and Malmberg 2015; Reardon et al. 2008).

Second, we examine whether racial diversity at the place level (i.e., the emergence of "global" or racially diverse communities) leads to less residential segregation between black and white. To test the buffering hypothesis, we apply hierarchical linear modeling (HLM) techniques to evaluate the relationship between diversity and black-white segregation while also taking into account other confounding place and metro (nonmetro) characteristics (e.g., black-white income). Place diversity is measured using: 1) a 15-category racial typology of diversity, adapted from Logan and Zhang's (2010) recent study of "global neighborhoods;" and 2) the entropy score $(E)$, a multigroup summary measure of diversity. We compare statistics across nested models to assess the extent to which place diversity, 
as well as our other place predictors (level one variables), accounts for place-toplace variation in levels and trends in black-white residential segregation across metropolitan (metro) and nonmetropolitan (nonmetro) areas (level two variables). This is an important task. According to Crowder, Pais, and South (2012:349), "the stability, change, and composition of integrated neighborhoods, and future trajectories of residential segregation, will likely be constrained by the specific economic, social, and spatial features of metropolitan areas." Metropolitan (and, we argue, nonmetro) areas circumscribe interconnected systems of places that are differentiated by their unique ecological location (e.g., along a river or highway), economic base, and social and demographic composition, including racial and ethnic diversity.

Third, and finally, we examine the extent to which places shift from one type of community to another over the 1990-2010 period, focusing in particular on whether growing place diversity is accompanied by white population growth or decline (i.e., depopulation due to "white flight"). Indeed, our analyses show that the racial classifications of places are highly fluid, as different types of places gain and lose different racial groups over time. Our dynamic place approach identifies possible demographic mechanisms (e.g., differential growth and decline of specific racial groups) responsible for declines in black-white segregation over the study period.

\section{Background}

Historically, the black population of the United States has been highly segregated from whites, especially in comparison to Asian and Hispanic populations (Frey and Farley 1996; Massey and Denton 1993). Logan and Stults (2011) show that black-white neighborhood segregation (measured with the index of dissimilarity) nevertheless declined from an average of 67 in 1970 to 59 in 2010 in the 50 largest U.S. metro areas. ${ }^{1}$ At the same time, black-white segregation in 2010 (59) exceeded Asian-white (41) and Hispanic-white (48) segregation levels and, over the 1990-2010 period, neighborhood exposure of African Americans to whites hardly changed at all. In 1990, the average black person lived in a neighborhood that was 34 percent white; by 2010, this percentage had increased only slightly to 35 percent.

By any standard, black-white segregation remains exceptionally high, especially when compared to segregation of other minority populations. Such results suggest that recent claims of the so-called "end of the segregated century" are premature (Glaeser and Vigdor 2012). More generally, observed declines in black-white segregation arguably must be considered in the context of possibly divergent patterns of multiracial, multiethnic diversity at different levels of geography. Virtually all-white neighborhoods remain commonplace at the urban fringe and in rural communities (Lichter 2012). Racial and ethnic diversity is unfolding unevenly across big cities, suburban communities, and small towns, a conceptual and measurement issue that we address in this study.

\section{Diversity and Segregation: The Buffering Hypothesis}

Our place-based approach acknowledges that communities are political actors that represent many competing political and economic interests (e.g., local businesses, 
municipal governments, school districts, neighborhood associations, and planning districts) that affect the inclusion or exclusion of specific groups, including minority populations (Massey, Rothwell, and Domina 2009). Segregation studies increasingly emphasize the political economy of places (Rugh and Massey 2010) beyond just neighborhoods or metro regions. This is because the administrative boundaries of places represent economic, cultural, and racial boundaries that cordon off or separate racially different populations-majority from minority. Rather than being restricted to neighborhoods (based on tract data), political or economic battles are often fought between places that hope to attract particular residents (e.g., affluent taxpayers) or commercial activities while excluding others (Lichter, Parisi, and Taquino 2012; Massey, Rothwell, and Domina 2009). Farrell (2008:467) claims that " $[\mathrm{u}]$ rban and suburban municipalities are replacing neighborhoods as the central organizing units of metro segregation." Places also arguably represent legal containers for understanding local politics and land use in the small towns of the United States (Lee, Iceland, and Farrell 2014; Lichter et al. 2007). As organized collective actors, places can include or exclude specific populations while either promoting or discouraging ethnoracial diversity and intergroup relations.

Previous research on racial diversity and black-white segregation has nevertheless focused almost exclusively on metro neighborhood segregation and change (e.g., invasion-succession processes). Diversity and segregation are sometimes viewed as opposing endpoints on a continuum of racial dominance (Holloway, Wright, and Ellis 2012), such that growing neighborhood diversity implies less racial segregation. In fact, the passage of Civil Rights legislation (e.g., the Fair Housing Act of 1968) and the massive immigrant influx of Hispanics and Asians following the Immigration and Nationality Act of 1965 opened up white neighborhoods to racially and ethnically diverse populations. Denton and Massey (1991:46) reported that about 30 percent of all-white metro neighborhoods in 1970 remained all-white by 1980; all-white neighborhoods represented less than five percent of all neighborhoods included in their study. An early study of changing diversity in the New York metro area found that all-white neighborhoods declined from 29 percent in 1970 to seven percent in 1990 (Alba et al. 1995). Friedman (2008) similarly found that all-white tracts dropped from 54 percent to 28 percent during the 1990s in the 61 largest U.S. metro areas (more than one million residents).

Growing metro diversity continued into the 2000s (Lee, Iceland, and Farrell 2014; Tienda and Fuentes 2014). Logan and Zhang (2010) now suggest that whites and other racial and ethnic groups increasingly share the same geographic space in so-called "global neighborhoods," where whites, African Americans, Hispanics, and Asians are present in significant numbers (i.e., at least 25 percent of the groupspecific average for U.S. metro areas). The demographic implication is that whites and diverse minority populations-including African Americans-may now coexist in harmony in stable rather than transient neighborhoods. Indeed, neighborhood growth of Hispanics and Asians may effectively serve as a "buffer" between white and black while both reducing the salience of race and diffusing racial animus.

Although our census-based analytic approach cannot adjudicate competing claims about the underlying demographic and behavioral mechanisms that ani- 
mate the buffering hypothesis, we can point to alternative views that counter the traditional place stratification model. For example:

1. Interracial contact in diverse neighborhoods and communities may encourage mutual understanding and tolerance, which presumably will promote processes of racial residential integration and reduce racial discrimination. This claim derives from Allport's (1954) well known contact hypothesis.

2. The expanding presence of nonblack minority populations, including Hispanics and Asians, may dampen white flight through the creation of spatially based buffer zones that reduce the geographic proximity of whites and blacks within neighborhoods (Frey and Farley 1996). Nonblack minorities may serve as associational brokers between black and whites, stitching together new formal and informal interracial mixing in diverse neighborhoods.

3. The entry of nonblack minorities may affect housing markets in ways that accelerate neighborhood transitions, including shifts to stable racial and ethnic neighborhoods and communities. Lee, Iceland, and Farrell (2014:438) suggest that the new presence of Hispanics might "alert real estate agents, lenders, and residents to a new, more diverse housing market in which discriminatory practices that target any single minority group are less likely to have the intended impact."

4. The "invisibility-discrimination" hypothesis suggests the presence of other minority groups in the neighborhood or community may render blacks "less visible," reduce the perceived "black threat" that sometimes accompanies black population increases, and dismantle the old black-white paradigm that undergirds black exceptionalism (Taylor 2008). Black-white segregation will decline as a result.

5. The growth of more diverse (and less diverse) communities presumably reflects the in- and out-migration of different population groups with different levels of racial and ethnic tolerance (Crowder, Pais, and South 2012). That racially intolerant populations (including whites) typically leave diversifying communities, while tolerant populations of all races are attracted to diversity, has the putative demographic effect of reducing segregation and promoting residential integration and positive interracial relations.

In fact, Frey and Farley's (1996) analyses of data from the 1980s showed that declines in black-nonblack segregation were most prominent in multiethnic metro areas, which they defined simply as having at least two overrepresented minority populations (i.e., Asian, Hispanic, or black). The empirical evidence was clearly consistent with the buffering hypothesis, at least for the 318 metro areas included in their study.

More recently, Iceland (2004) similarly addressed the buffering hypothesis, asking whether more diverse metro areas became less segregated over the 19802000 period. Unlike Frey and Farley (1996), he found that racial and ethnic diversity, as measured by the entropy score, was positively associated with increasing racial and ethnic segregation (using a multigroup measure of segregation). Iceland (2004) 
did not focus on black-white segregation, but he showed that increasing metro diversity was associated with both declining black segregation from other groups and increasing white segregation from minority populations. Iceland (2004:269) interpreted these results to be mostly consistent with the buffering hypothesis: "[M]ultiple minority groups may be moderating the single minority vs. white majority thinking that dominated in the past." Interestingly, his results also showed that a growing black population was associated with increasing overall racial and ethnic segregation between 1980 and 2000, especially among whites who evidently sought racial separation from minority populations.

The support that these previous studies (Frey and Farley 1996; Iceland 2004) provide for the buffering hypothesis is perhaps equivocal; indeed, other recent studies now suggest a new pattern of "hunkering down" by whites in response to the demographic threat of growing racial diversity (Putnam 2007). This pattern may be most evident in communities where the past half-century has brought unusually rapid minority population growth and new majority-minority populations (Johnson and Lichter 2010). In fact, using microdata from the Panel Survey of Income Dynamics, South, Crowder, and Pais (2011) find that whites in particular seemed to be motivated to self-segregate in those metro areas with large black populations. There is little evidence that either blacks or whites are actually moving into multiethnic neighborhoods (Crowder, Pais, and South 2012; Logan and Zhang 2010). Other studies show that the U.S. white population declined most rapidly in multiracial settings but grew in low-diversity areas (Farrell and Lee 2011). Iceland, Sharp, and Timberlake (2013) also report that black-white residential contact (using the exposure index) is actually lower in metro areas with larger nonblack minority populations, a finding that seemingly is consistent with both a pattern of hunkering down among whites and with white depopulation in rapidly diversifying big city neighborhoods.

\section{Macro-Segregation and Geographic Inclusivity}

Metro-centric approaches to segregation typically fail to acknowledge that racial diversity - or its opposite-is occurring at multiple geographic levels (see Lee et al. 2008). Most communities, whether they are large immigrant gateways or small towns in the nation's heartland, have grown more racially diverse over the past two decades (Lee, Iceland, and Farrell 2014; Lichter 2012). A new macro-segregation may nevertheless be emerging, of which neighborhood or micro-segregation is only one part, albeit a significant one (Fischer et al. 2004; Lee et al. 2008; Parisi, Lichter, and Taquino 2011). For example, with long-term declines of all-white big city neighborhoods (Denton and Massey 1991; Friedman 2008), it is perhaps unsurprising that the number of majority-minority populations among the nation's largest 100 cities increased from 43 to 58 in the 2000s. Detroit, for example, lost virtually half of its population between 1970 and 2010 (1.5 million to 707,000 people), while the black percentage of the population increased to 83 percent. The demographic paradox is that this unprecedented racial transformation of U.S. cities (e.g., Detroit, Baltimore, and St. Louis, among many others) has occurred in tandem with observed declines in black-white (and black-nonblack) neighborhood segregation. 
This raises a straightforward question: Should growing neighborhood diversity continue to be interpreted as evidence of eroding racial boundaries when, at the same time, whites are declining absolutely and relatively in the nation's largest cities and in most big city neighborhoods? Despite rather limited or mixed empirical evidence-and none during the past decade-the typical view is that the new diversity of the United States has mostly salutary implications for the black-white color line (as measured by residential segregation). Yet some of the most affluent and racially homogenous places in the United States are located outside central cities and even beyond urbanized areas (e.g., in gated communities located at the urban-rural fringe or in high-amenity nonmetro counties) (Lee, Iceland, and Farrell 2014). In small suburban and nonmetro places, for example, the number of majority-minority communities has nearly tripled since 1990 (Lichter 2012). The question of whether growing diversity has blurred the U.S. color line remains largely unanswered, even as the answer provides, more than ever before, a window to the racial future of the United States as we move inexorably toward a majority-minority society by 2043 (U.S. Census Bureau 2012). Declining segregation in the nation's largest cities may be offset by increases in segregation between places, both big and small.

\section{Current Study}

In this study, we address the question of whether blacks experience lower segregation from whites in places that are more racially diverse. We build on previous studies of the buffering hypothesis by making several specific contributions to the literature. First, our analyses, using up-to-date data, span two decades of extraordinary demographic change. Our study highlights growing diversity over a period of unprecedented increases in the U.S. minority population, as well as the centrifugal drift of minorities away from traditional areas of metro settlement.

Second, unlike previous studies that focus on metro areas, a major objective here is to provide a geographically inclusive analytic framework for studying racial residential segregation, one that acknowledges that metro and nonmetro areas represent systems of places-cities, suburbs, and small towns-that shape the ethnic and racial profiles of neighborhoods. Metro central cities today comprise only about 30 percent of the total U.S. population and an even smaller share of the white population (U.S. Census Bureau 2012). Further, suburban communities can no longer be considered an undifferentiated whole made up mostly of suburbanizing whites, especially if segregation is increasingly characterized by growing racial homogeneity from one suburban community to another-a distinct form of macrosegregation (Farrell 2008; Hall and Lee 2010). In addition, many small towns, both in the exurbs outside urbanized areas and in remote rural areas, have become havens for affluent whites, while others have become new destinations for Hispanic immigrants looking for work. In an age of unprecedented growth of minority populations in the United States and uneven geographical spread in racial diversity (Johnson and Lichter 2010; Lee, Iceland, and Farrell 2014), a definitive test of the buffering hypothesis arguably requires a spatially inclusive conceptual and empirical approach. 
Third, we measure racial diversity in a comprehensive way with the entropy score (Lee, Iceland, and Farrell 2014), and with a new racial typology adapted from Logan and Zhang (2010), applied for the first time to places rather than neighborhoods. We also appropriately focus on black-white rather than blacknonblack segregation (Iceland 2004), which is confounded by rapidly changing shares of the nonblack-nonwhite population of Hispanics and Asians over the past two decades.

\section{Data and Methods}

\section{Places as Units of Analysis}

Places, as defined by the U.S. Census Bureau, represent our units of analysis. The definition includes all incorporated cities, towns, and villages, as well as unincorporated communities and housing developments (called "census designated places") that lack municipal governments. The specific places included in the analysis were selected on two primary criteria. First, based on the rationale outlined by Lee, Iceland, and Farrell (2014), we identified all places with at least 1,000 residents in 1990, 2000, and 2010 - that is, we focused on a fixed number of places throughout the study period. This selection criterion yielded an initial sample of 12,371 places. This total was reached by eliminating 8,350 places that had fewer than 1,000 residents in each census year, as well as 1,119 places that had fewer than 1,000 in at least one decade. Second, we identified a subset of these 12,371 places where at least 90 percent of the population was composed of non-Hispanic whites, non-Hispanic blacks, Asians, or Hispanics. This selection criterion eliminated small places (369) composed of multiracial groups and Native Americans, Pacific Islanders, and Eskimos, groups that typically have little or no spatial connection to African Americans (and thus to black-white segregation).

Overall, 12,002 places were included in the analysis. These places captured 67.2 percent of the total U.S. population in 2010. They represented 60.3 percent of all whites in the United States, 78.4 percent of all blacks, 83.2 percent of all Hispanics, and 80.2 percent of all Asians. Whites clearly are much more spatially dispersed than are racial and ethnic minorities in the United States. That is, whites are more likely to be living in very small places of less than 1,000 people, on farms, in the countryside, and in unincorporated housing developments at the urban-rural fringe. ${ }^{2}$

\section{Measurement}

\section{Black-White Segregation}

Place-based segregation is our dependent variable. For each place, we use block data from the 1990-2010 decennial censuses to measure racial residential segregation with the index of dissimilarity $(D)$. The data used to highlight changing segregation and diversity of places come from the 100 percent items of the 1990, 2000, and 2010 
decennial censuses. The index of dissimilarity, $D_{t}$, is defined as:

$$
D_{t}=\frac{1}{2} \sum_{i=1}^{k}\left|b_{i t}-w_{i t}\right|
$$

where $b_{i t}$ and $w_{i t}$ are the respective percentages of the black and white populations residing in census block $i$ at time $t$. This index is based on pairwise comparisons and varies from 0 (no black-white segregation) to 100 (complete segregation). $D$ indicates the percentage of blacks (or whites) that would have to move to other blocks in order to achieve parity between blacks and whites in their percentage distributions across all blocks in a given place. $D$ remains the workhorse of segregation studies, mostly because of ease of computation and interpretation; it also satisfies the need for appropriate comparisons with previous studies of neighborhood segregation.

For the purposes of this study, blocks provide spatial units that can be aggregated to legal boundaries of places, unlike census tracts. Blocks are the smallest geographic units for which 100 percent data are made available by the U.S. Census Bureau; thus, our estimates of segregation and diversity are not subject to sampling variability. Blocks are conceptualized as spatial containers that provide a more granular picture of spatial distributions of racial and ethnic groups within places (Lichter et al. 2007; 2010).

\section{Racial and Ethnic Diversity}

To gauge the significant local presence of racial and ethnic groups, we adapt the neighborhood typology of Logan and Zhang (2010) to places. Specifically, we use a 25 percent decade-specific criterion that we apply separately to metro central cities, suburban places, and nonmetro places. For any given racial group to be considered "present," it must account for at least 25 percent of the decade's groupspecific average for all U.S. metro central cities. A similar approach was used to identify types of places among metro suburban places and nonmetro places, using their respective group-specific averages. We use a constant definition (in 2009) of metropolitan and nonmetropolitan areas, as defined by the Office of Management and Budget, for the 1990-2010 period (U.S. Census Bureau 2013). Our typology identifies places that are virtually all white, all black, all Hispanic, all Asian, and everything in between. Our analysis yields appropriate racial distributions for different types of places, seemingly validating our adaptation of Logan and Zhang's (2010) typology (see appendix Table A). For example, in 2010, places classified as having significant white and black populations (designated WB communities) were, on average, 71.3 percent white, 24.7 percent black, 1.6 percent Hispanic, and 0.3 percent Asian. The average proportion Hispanic in communities that were classified as Hispanic-only (H communities) was 91.7 percent in 2010.

We also use the entropy score $(E)$ as a summary measure of the extent to which the four main racial groups are present in equal shares in a place. $E$ is defined as:

$$
E=\sum_{r=1}^{n} p_{r} \ln \left(\frac{1}{p_{r}}\right)
$$


where $p_{r}$ refers to the proportion of the population of racial group $r$ in a place, and $n$ indicates the number of groups under consideration (in our case, four). The maximum possible value of $E$ (the natural $\log$ of $n$ ) is obtained only when all groups are of equal size in a place. Since there is no fixed upper bound, a place consisting of more equal-sized groups will produce a higher $E$ score than one consisting of fewer equal-sized groups. An $E$ of 0 (complete homogeneity) means that the place contains a single group. Dividing $E$ by its maximum value for the given $n$ standardizes it to a $0-1$ range. We have multiplied the standardized scores by 100 so that 0 equals the lowest level of diversity and 100 the highest.

\section{Other Place and Metro(Nonmetro) Level Variables}

We created two additional sets of independent variables. One set was designed to gauge place characteristics (level one variables in our HLM), including the aforementioned two measures of racial and ethnic diversity. The other measured structural and functional dimensions of the metro and nonmetro areas in which places were embedded (level two variables). This is a time-intensive technical task that involved linking each place to the metro or nonmetro area in which it is located. Following previous studies (Iceland 2004; Logan, Stults, and Farley 2004), we identify various control variables for our multivariate analysis of segregation, which are measured using place data from the 1990 and 2000 decennial censuses (Summary File 3) and 2007-2011 American Community Survey, which replaced the long form of the 2010 decennial census.

Population size is measured as the natural log of the population of a place, to account for skew in the size distribution of places. Income is defined as median household income by racial group. Specifically, we measure the ratio of black or other minority median household income to white median household income. The closer black income is to white income, the less segregated blacks are expected to be from whites; economic incorporation accelerates spatial assimilation (Farley and Frey 1994; Logan, Stults, and Farley 2004).

Change in housing stock is the percentage change in housing built between 1990 and 2010 (Iceland, Sharp, and Timberlake 2013). Growth in housing stock is expected to be positively associated with segregation (Farley and Frey 1994; Logan, Stults, and Farley 2004). This hypothesis reflects the empirical reality of continuing white suburbanization and exurbanization, which serve as demographic mechanisms that separate whites from other groups, including blacks.

Functional specialization is defined with a set of dummy variables classifying the economic base of a place as retirement, manufacturing, government, education, or military. First developed by the USDA's Economic Research Service using 1979 data and regularly updated, the functional specialization of a place is based on whether the community is at least one standard deviation above the average for the percentage of the population in a specialization (for a full description, see Economic Research Service 2013). The general expectation is that retirement and manufacturing communities tend to have higher levels of residential segregation than their counterparts with education, military, or government specializations (Lichter et al. 2007; Logan, Stults, and Farley 2004). 
We identify places that annexed territory (incorporated adjacent areas into their municipal boundaries) between 1990 and 2010 by overlaying 2010 place boundaries and blocks on those for 1990. Previous studies show that higher residential segregation is associated with annexation, a political process that involves the incorporation of mostly white, high-income populations at the periphery (Lichter et al. 2007). We also use dummy variables to distinguish central/principal cities from suburban places in metro counties. Similarly, we use a dummy variable to distinguish principal cities in nonmetro (micropolitan) counties from other nonmetro places.

We also include three measures that reflect the influence of recent demographic change on segregation within place boundaries over the 1990-2010 period. In addition to change in housing stock (defined earlier), change in relative minority population growth is defined as the difference between the minority and white population growth rates in places. Change in income between 1990 and 2010 is computed as the difference in minority-white income ratios in places.

We use four major indicators to assess the influence of metro (nonmetro) areas on the levels and trends of racial residential segregation within places (level two variables). The natural $\log$ of the total population was used to gauge the impact of area size on local processes of neighborhood differentiation. Previous studies indicate that segregation is higher in larger metro areas (Logan, Stults, and Farley 2004).

The racial diversity of places (alternatively measured) is also linked to the racial composition of the larger region. Regional diversity could give rise to a more racially segregated system of places. For example, a majority-minority place has a different meaning in a majority-minority metro area than it does in a largely white metro area. Studies show that differences in racial attitudes and tensions across neighborhoods increase with the overall size of the minority population in metro areas (Oliver and Wong 2003). Here, we gauged the overall racial context as the percentages of blacks, Asians, and Hispanics living in a metro (nonmetro) area.

We also measure political fragmentation of the metro (nonmetro) area. Farley and Frey (1994) argue that places use land use zoning and other methods as exclusionary tactics. As a result, blacks in highly fragmented areas tend to be more segregated than those in less fragmented areas. In this study, we measure political fragmentation as the number of places in the metro (nonmetro) area per 1,000 population (see Crowder, Pais, and South 2012). Finally, we include the region of the metro (nonmetro) area, which is operationalized as a set of dummy variables classifying places as falling within the census-defined West, Midwest, Northeast, or South regions (Iceland, Sharp, and Timberlake 2013).

\section{Analytical Strategy}

The analysis begins with a baseline description of changing patterns of diversity in U.S. places, if only to reinforce evidence of the unprecedented racial transformation across the U.S. landscape. We then report observed patterns of association between place diversity, variously measured, and black-white segregation.

We recognize, of course, that segregation measured at the place level could mask segregation occurring between places within specific metro and nonmetro areas. For example, metro areas are sometimes viewed as better representations of housing markets; that is, compared with places, metro areas contain a broader range of 
specific neighborhoods that people can theoretically choose from. To address this issue, our analyses estimate the within-metro (nonmetro) and between-metro (nonmetro) components of changing black-white segregation. This is accomplished by estimating various HLMs of: 1) black-white segregation in 2010; and 2) 1990-2010 change in black-white segregation. Our modeling approach is well suited to the multilevel data we have constructed for this purpose; blocks are nested within places, which are nested within specific metro or nonmetro areas. We estimate several sets of models for metro and nonmetro places that include separately each measure of diversity. To facilitate the interpretation of place and metro (nonmetro) effects, all the variables measured on a ratio scale were centered on their grand mean. We also estimate the intra-class correlation coefficient (ICC) to highlight the percentage of the total variance in black-white segregation within and between metro (nonmetro) areas. Our multilevel approach allows us to determine the extent to which diversity, along with socioeconomic, demographic, and ecological differences from place-to-place or from metro-to-metro (nonmetro-to-nonmetro) area, accounts for observed differences in patterns of black-white residential segregation.

Finally, we finish with an empirical coda on the link between growing diversity, declining black-white segregation, and white depopulation. These results provide additional insight into the possible demographic mechanisms underlying declining segregation in diversifying places, while also reinforcing our call for greater geographic inclusivity in the study of racial and ethnic segregation.

\section{Results}

\section{Diversity of Places, 1990-2010}

We examine the uneven distribution of diversity across all places, in both metro and nonmetro areas. For each of the 15 types of places included in our typology, Table 1 presents the number of places and $E$ in 1990 and 2010. Each place is designated by letter combinations of W (white), B (black), H (Hispanic), and A (Asian) to indicate the significant presence of a specific group in the place (as described in the methods section). For example, the number of all-white places (W) in metro areas declined from 1,434 to 990, or by roughly 30 percent, between 1990 and 2010. Similarly, all-white places in nonmetro areas declined from 685 to 313, or by more than 55 percent. Clearly, all-white metro, suburban, and rural places are on the decline nationally. This demographic fact is also reflected in $E$, which, on average, increased from 26.4 in 1990 to 40.0 in 2010 among metro places and from 21.2 to 30.4 among nonmetro places during the same period.

America's growing diversity is also revealed in places with significant numbers of each of the four racial and ethnic groups (WBHA); in metro areas, these places increased in number from 1,483 to 2,442 between 1990 and 2010. They nearly tripled in nonmetro areas, from 298 in 1990 to 813 in 2010. Clearly, the growing diversity of America's neighborhoods (Logan and Zhang 2011) and of the nation's overall population (Johnson and Lichter 2010; Lichter 2013) is also reflected in the rapid growth of racially diverse places across the United States (Lee, Iceland, and Farrell 2014). The average $E$ in the most racially diverse metro places (i.e., places labelled 
Table 1: Place Characteristics, 1990-2010

\begin{tabular}{lrrrrrrrr}
\hline & \multicolumn{3}{c}{ Number of places } & \multicolumn{4}{c}{ Entropy index (E) } \\
Place & \multicolumn{3}{c}{ Metro } & \multicolumn{1}{c}{ Nonmetro } & \multicolumn{3}{c}{ Metro } & Nonmetro \\
Typology & 1990 & 2010 & 1990 & 2010 & 1990 & 2010 & 1990 & 2010 \\
\hline WBHA & 1,483 & 2,442 & 298 & 813 & 49.9 & 60.2 & 44.2 & 53.2 \\
WBH & 383 & 507 & 200 & 97 & 43.0 & 52.6 & 48.6 & 55.2 \\
WBA & 702 & 507 & 421 & 342 & 30.6 & 37.7 & 36.7 & 41.0 \\
BHA & 38 & 133 & 1 & 10 & 53.7 & 63.2 & 41.5 & 49.3 \\
WHA & 1,376 & 1,452 & 704 & 1,179 & 27.8 & 39.3 & 20.0 & 28.9 \\
WB & 792 & 395 & 416 & 108 & 31.5 & 36.7 & 38.8 & 40.0 \\
WH & 538 & 584 & 352 & 205 & 20.2 & 27.6 & 17.7 & 25.1 \\
WA & 1,144 & 739 & 798 & 779 & 10.3 & 18.3 & 5.9 & 10.9 \\
BH & 31 & 79 & 5 & 5 & 43.5 & 46.9 & 17.7 & 30.7 \\
BA & 4 & 13 & 6 & 20 & 27.8 & 39.3 & 20.1 & 31.8 \\
HA & 46 & 73 & 10 & 23 & 38.1 & 38.1 & 28.0 & 30.5 \\
W & 1,434 & 990 & 685 & 313 & 5.7 & 10.4 & 4.0 & 7.1 \\
B & 40 & 55 & 13 & 21 & 20.0 & 23.8 & 24.8 & 22.8 \\
H & 58 & 100 & 24 & 18 & 19.1 & 19.8 & 21.3 & 21.3 \\
Total & 8,069 & 8,069 & 3,933 & 3,933 & 26.4 & 40.0 & 21.2 & 30.4 \\
\hline
\end{tabular}

WBHA) increased from 49.9 in 1990 to 60.2 in 2010 and in nonmetro places from 44.2 to 53.2. Not unexpectedly, $E$ was lowest in all-white places in both metro and nonmetro areas-10.4 and 7.1, respectively.

Growing place diversity does not guarantee more integrated white-minority communities. In fact, the number of diverse places without a significant white population (i.e., $\mathrm{BHA}, \mathrm{BH}, \mathrm{BA}, \mathrm{HA}, \mathrm{B}$, and $\mathrm{H}$ combined $^{3}$ ) increased rapidly over the last 20 years. These "minority places" increased from 217 to 453 in metro areas and from 59 to 97 in nonmetro areas. All-black and all-Hispanic metro places also increased over the study period, together increasing from 98 to 155; they increased from 37 to 39 in nonmetro areas. Perhaps surprisingly, all-black nonmetro places (B) grew between 1990 and 2010 from 13 to 21, while all-Hispanic nonmetro places $(\mathrm{H})$ declined from 24 to 18. These data clearly highlight the complicated dynamics of racial and ethnic change in U.S. cities, suburbs, and rural places, but one lesson is clear: growing diversity does not always connote integration with whites. A new macro-segregation also may be emerging (Parisi, Lichter, and Taquino 2011), with mostly minority places separated from mostly white places.

\section{Diversity and Segregation, 1990-2010}

As racial diversity unfolds unevenly over geographic space, what are the implications for black-white segregation? As a starting point, we report both the overall unweighted and weighted Ds for both metro (central city and suburban) and nonmetro places (Table 2). Unweighted Ds represent the average experience of U.S. places; they give equal weight to each place, regardless of its size. This unweighted 
Table 2: Decade-Specific Place Average (Unweighted) Black-White Indices of Dissimilarity $(D)$ by Place Typology

\begin{tabular}{lcccccc}
\hline \multirow{2}{*}{ Place typology } & \multicolumn{3}{c}{ Metro } & \multicolumn{3}{c}{ Nonmetro } \\
\hline WBHA & 1990 & 2000 & 2010 & 1990 & 2000 & 2010 \\
WBH & 55.6 & 53.9 & 51.2 & 68.7 & 64.9 & 60.8 \\
WBA & 70.7 & 65.0 & 59.1 & 78.0 & 70.0 & 65.8 \\
BHA & 61.3 & 57.2 & 52.7 & 73.3 & 67.4 & 62.5 \\
WHA & 54.2 & 53.6 & 46.6 & 96.6 & 72.2 & 67.8 \\
WB & 71.7 & 69.7 & 66.4 & 86.0 & 84.3 & 82.1 \\
WH & 70.9 & 64.2 & 60.3 & 75.7 & 67.3 & 63.1 \\
WA & 82.4 & 81.0 & 79.0 & 89.7 & 88.5 & 88.9 \\
BH & 76.0 & 73.7 & 67.9 & 88.2 & 86.6 & 83.8 \\
BA & 70.7 & 56.8 & 60.6 & 86.5 & 72.2 & 72.8 \\
HA & 38.7 & 47.5 & 40.7 & 67.3 & 68.9 & 69.9 \\
W & 71.6 & 73.4 & 67.6 & 89.7 & 84.5 & 85.1 \\
B & 84.0 & 82.3 & 79.4 & 90.9 & 88.3 & 89.0 \\
H & 55.4 & 56.3 & 54.1 & 75.3 & 73.4 & 68.8 \\
Total (unweighted) & 86.0 & 85.7 & 82.5 & 92.7 & 90.4 & 96.0 \\
Total (weighted) & 70.5 & 67.2 & 62.4 & 82.4 & 79.1 & 76.0 \\
\hline
\end{tabular}

scheme conforms most closely to our conceptual emphasis on places rather than people. On the other hand, the weighted Ds represent the typical or average experience of blacks across different types of communities-both racially diverse and racially homogenous. Here, $D$ s are weighted by the size of the black population in each place, which means that heavily populated black places are given more weight than small places. The two measures provide useful but different inferences.

Regardless of weighting scheme, our overall place-based estimates reveal temporal declines in black-white segregation in both metro and nonmetro places. As shown in Table 2, black-white metro segregation (as measured with the unweighted $D$ ) declined on average from 70.5 in 1990 to 62.4 in 2010. In nonmetro areas, the unweighted $D$ declined from 82.4 to 76.0 , while the weighted Ddeclined from 75.6 to 62.6 .

To put these segregation estimates in perspective, Logan and Stults (2011) reported unweighted Ds of 67 and 59 in 1990 and 2010, respectively, in a tract-based study of the 50 most populated metro areas. These comparative results are reassuring from a methodological and theoretical standpoint. Our results, based on place and block data, indicate that previous studies of metro segregation accurately represent levels and trends in black-white segregation in the United States. Equally important, they also clearly reveal that black-white segregation is often substantial in places not typically considered in previous segregation studies (i.e., specific suburban communities and small towns).

Is black-white segregation low in diverse communities? Table 2 reports the levels and trends in black-white (unweighted) segregation for different places in our racial 
Table 3: Place Transitions and Decade-Specific B-W Indices of Unweighted Dissimilarity (D), 1990-2010

\begin{tabular}{lcccccc}
\hline & \multicolumn{3}{c}{ Metro } & \multicolumn{3}{c}{ Nonmetro } \\
1990-2000 Place Transition & 1990 & 2000 & 2010 & 1990 & 2000 & 2010 \\
\hline Gain diversity & 72.2 & 66.7 & 59.8 & 82.5 & 78.5 & 74.5 \\
Lose diversity & 69.6 & 68.4 & 66.2 & 83.2 & 80.7 & 80.9 \\
No diversity change & 69.2 & 67.1 & 63.2 & 82.3 & 79.6 & 76.5 \\
Shift composition & 73.3 & 69.6 & 65.0 & 81.0 & 78.0 & 75.1 \\
\hline
\end{tabular}

typology. The results suggest two main conclusions. First, in both metro and nonmetro places with a significant black presence, average black-white segregation declined over the 1990-2010 period in every instance, except in BA places, where black-white segregation increased slightly from 38.7 to 40.7 in metro areas and from 67.3 to 69.9 in nonmetro areas. In metro areas, the largest absolute declines in black-white segregation were observed in WBH places (70.7 to 59.1)-i.e., in diverse places with large Hispanic shares. In contrast, the largest decline in nonmetro areas was experienced in all-minority BHA places that had no significant white presence (96.6 to 67.8).

Second, metro and nonmetro places with the highest levels of black-white segregation are those that have a white presence but not a black presence $(\mathrm{W}, \mathrm{WH}$, and WA). Interestingly enough, white places that have little or no presence of blacks are on the decline numerically (see Table 1). Blacks clearly have made inroads into these places, but our results also indicate that the small shares of blacks living in white communities (including those with Asian and Hispanic presences) are cordoned off from whites, if measured by black-white segregation.

What happens when places become more diverse over time? Table 3 reports the level of black-white segregation for metro and nonmetro places that: 1) increased in diversity by adding either Hispanic, Asian, or both; 2) remained stable in the number and type of groups present; 3 ) lost diversity (e.g., changed from WBA to WA); and 4) shifted composition (e.g., from WBA to WBH). As before, declines in blackwhite segregation occurred across many different types of metro and nonmetro places-both stable places and those that became more diverse in our typology. Most significant is that metro and nonmetro places experiencing transitions toward more diversity experienced large declines in black-white segregation: $D$ declined from 72.2 in 1990 to 59.8 in 2010 in metro places under such conditions, and from 82.5 to 74.5 in nonmetro places.

\section{Multilevel Models of Black-White Segregation}

\section{Diversity and Black-White Segregation in 2010}

To test the buffering hypothesis, we fit black-white segregation models that include place-based measures of racial and ethnic diversity based on our adaptation of Logan and Zhang's (2010) neighborhood typology, followed by models that include 
Table 4: Descriptive Statistics

\begin{tabular}{|c|c|c|c|c|}
\hline & & etro & Nonr & netro \\
\hline & Mean & SD & Mean & SD \\
\hline Place control variables, 2010 & & & & \\
\hline Total population, 2010 & 23,240 & 123,122 & 5,092 & 6,183 \\
\hline Minority representation & & & & \\
\hline Percent black & 9.2 & 16.3 & 9.7 & 18.7 \\
\hline Percent hispanic & 12.3 & 18.1 & 8.9 & 15.3 \\
\hline Percent asian & 3.1 & 5.5 & 0.7 & 1.0 \\
\hline Economic characteristics & & & & \\
\hline White median income & 74,382 & 30,183 & 51,374 & 13,104 \\
\hline Black median income & 58,547 & 42,040 & 31,180 & 21,053 \\
\hline \% of housing units built since 1990 & 74,382 & 30,183 & 51,374 & 13,104 \\
\hline Annexation since 1990 ( $1=$ annexed, $(0=$ otherwise $)$ & 68.1 & & 83.2 & \\
\hline Functional specialization & & & & \\
\hline Retirement $(1=$ retirement, $0=$ otherwise $)$ & 5.5 & & 14.8 & \\
\hline Manufacturing $(1=$ manufacturing, $0=$ otherwise $)$ & 26.9 & & 40.2 & \\
\hline Government ( 1 =government, $0=$ otherwise $)$ & 6.8 & & 6.1 & \\
\hline Military $(1=$ military, $0=$ otherwise $)$ & 4.1 & & 2.3 & \\
\hline School ( 1 =school, $0=$ otherwise $)$ & 17.0 & & 7.6 & \\
\hline No specialization $(1=$ none, $0=$ otherwise $)$ & 39.6 & & 29.1 & \\
\hline Central $/$ principal city $(1=$ central, $0=$ otherwise $)$ & 8.6 & & 14.3 & \\
\hline Level 2 controls & & & & \\
\hline Total population, 2010 & 500,283 & $1,327,422$ & 12,023 & 19,086 \\
\hline Racial composition & & & & \\
\hline Percent black & 12.5 & 9.0 & 7.5 & 14.3 \\
\hline Percent hispanic & 14.2 & 14.3 & 7.8 & 13.0 \\
\hline Percent asian & 4.3 & 4.2 & 0.6 & 0.6 \\
\hline Political fragmentation & 33.2 & 65.5 & 3.3 & 3.6 \\
\hline Region & & & & \\
\hline South ( $1=$ south, $0=$ otherwise $)$ & 32.2 & & 38.7 & \\
\hline Northeast $(1=$ northeast, $0=$ otherwise $)$ & 16.6 & & 13.5 & \\
\hline Midwest ( $1=$ midwest, $0=$ otherwise $)$ & 26.2 & & 36.3 & \\
\hline West $(1=$ west, $0=$ otherwise $)$ & 25.0 & & 11.5 & \\
\hline
\end{tabular}

the alternative summary measure of diversity, $E$. The descriptive statistics for all variables are reported in Table 4 but are not discussed.

We begin in Table 5 with our discussion of the metro results based on the placebased diversity typology. With only one exception (BA places), the most diverse metro places-those with all four groups (i.e., with WBHA serving as the reference category) - had the lowest levels of black-white segregation, net of the place and metro controls included in the models. Black-white segregation differences in allblack places (B) and all-minority places (BHA) were not statistically different from 
WBHA places. These results tell a consistent story of lower black-white segregation in the most diverse places, but they also reveal that black-white segregation is low only in metro places with a significant black presence (B, BA, BHA, and WBHA) and that segregation is especially high (exceeding a 20-point difference in $D$ ) in metro places without any significant black presence-in $\mathrm{WH}, \mathrm{W}$, and $\mathrm{H}$ places.

The findings for nonmetro places reveal less striking but similar place-to-place patterns of black-white segregation. That is, the most diverse nonmetro places (WBHA, WBH, WBA, and BHA), along with black places (B), had the lowest blackwhite segregation. At the other extreme, places with any white presence but no black presence (i.e., W, WH, WA, and WHA), had the highest levels of black-white segregation. In nonmetro areas, as in metro areas, these results again suggest a clear pattern of black exceptionalism in minority segregation from whites (Parisi, Lichter, and Taquino 2011). Even with controls, blacks are most segregated from whites in places where they have contributed least to overall racial diversity.

Our models also include several other conventional predictors and control variables, which generally reveal expected results and straightforward interpretations (Table 5). These results are of secondary interest but nevertheless reveal several patterns worth noting. For example, in metro places, smaller black-white income inequality is, as expected, associated with lower levels of black-white residential segregation. Economic and spatial incorporation clearly go hand in hand. But this statistical relationship is not observed in nonmetro places, where blacks and whites remain highly segregated, apparently regardless of their incomes. Racial boundaries may be brighter in rural places, especially in the South (Lichter et al. 2007). It is also the case that lower black-white segregation is less pronounced in places that are dependent on public employment-in government, military, and education. Like previous research showing lower segregation in metro suburban areas (Iceland, Sharp, and Timberlake 2013), our analyses show that black-white segregation is significantly higher in principal cities $(B=3.10)$ than in suburban places. The same pattern is revealed in nonmetro areas but to a lesser degree $(B=1.87)$.

The models in Table 5 also include level two metro (nonmetro) control variables. In metro $(B=0.08)$ and nonmetro $(B=0.15)$ areas with large Hispanic shares, place-based black-white segregation is the highest. Any salutary effects on blackwhite segregation in racially diverse places are seemingly offset by increasing black-white segregation when large Hispanic population shares are considered at the metro (nonmetro) level. This result arguably is inconsistent with the buffering hypothesis and the notion that diversity desensitizes residents to racial composition. In addition, political fragmentation is associated with more place-based black-white segregation, especially in metro areas. Metro areas with larger numbers of places per 1,000 population have higher levels of black-white segregation. Of course, whether political fragmentation (the establishment of more places) is mostly a response to greater racial diversity (as whites hunker down in white suburban communities), or conversely promotes macro-segregation, remains an empirical question (Farrell 2008). Finally, consistent with a recent study by Iceland, Sharp, and Timberlake (2013), metro places in the Midwest and West have significantly higher black-white segregation than similar places in the South. The overall significance of these regional factors (and our multilevel approach) is further revealed in the high 
Table 5: Fixed and Random Effects from HLM Regressions of 2010 Black-White Residential Segregation on Place Typology and Other Place and Contextual Characteristics

\begin{tabular}{|c|c|c|}
\hline & Metro & Nonmetro \\
\hline Intercept & $\begin{array}{l}51.83 \dagger \\
(0.68)\end{array}$ & $\begin{array}{l}63.29 \dagger \\
(0.89)\end{array}$ \\
\hline \multicolumn{3}{|l|}{ Place typology, 2010} \\
\hline WBH & $\begin{array}{r}4.43 \dagger \\
(0.61)\end{array}$ & $\begin{array}{c}-0.96 \\
(1.16)\end{array}$ \\
\hline WBA & $\begin{array}{r}2.22 \dagger \\
(0.61)\end{array}$ & $\begin{array}{c}-0.10 \\
(0.79)\end{array}$ \\
\hline $\mathrm{BHA}$ & $\begin{array}{c}-1.84 \\
(1.04)\end{array}$ & $\begin{array}{c}0.09 \\
(4.30)\end{array}$ \\
\hline WHA & $\begin{array}{l}12.60 \dagger \\
(0.46)\end{array}$ & $\begin{array}{l}13.53 \dagger \\
(0.76)\end{array}$ \\
\hline WB & $\begin{array}{r}6.45 \dagger \\
(0.73)\end{array}$ & $\begin{array}{c}-2.02 \\
(1.16)\end{array}$ \\
\hline WH & $\begin{array}{l}21.02 \dagger \\
(0.79)\end{array}$ & $\begin{array}{l}15.89 \dagger \\
(1.27)\end{array}$ \\
\hline WA & $\begin{array}{l}12.77 \dagger \\
(0.64)\end{array}$ & $\begin{array}{l}16.80 \dagger \\
(0.87)\end{array}$ \\
\hline $\mathrm{BH}$ & $\begin{array}{r}7.89 \dagger \\
(1.35)\end{array}$ & $\begin{array}{l}11.71 * \\
(5.31)\end{array}$ \\
\hline BA & $\begin{array}{c}-7.02 * \\
(2.93)\end{array}$ & $\begin{array}{c}6.93 * \\
(2.85)\end{array}$ \\
\hline HA & $\begin{array}{l}14.56 \dagger \\
(1.63)\end{array}$ & $\begin{array}{l}22.29 \dagger \\
(5.27)\end{array}$ \\
\hline $\mathrm{W}$ & $\begin{array}{l}20.91 \dagger \\
(0.72)\end{array}$ & $\begin{array}{l}17.78 \dagger \\
(1.33)\end{array}$ \\
\hline B & $\begin{array}{c}1.27 \\
(1.67)\end{array}$ & $\begin{array}{c}1.11 \\
(2.64)\end{array}$ \\
\hline $\mathrm{H}$ & $24.29 \dagger$ & $15.28 \dagger$ \\
\hline \multicolumn{3}{|l|}{ Place controls } \\
\hline Total population, $2010(\ln )$ & $\begin{array}{r}-1.07 \dagger \\
(0.16)\end{array}$ & $\begin{array}{r}-2.53 \dagger \\
(0.41)\end{array}$ \\
\hline \multicolumn{3}{|l|}{ Economic characteristics } \\
\hline B-W median income ratio, 2010 & $\begin{array}{r}-1.41 \dagger \\
(0.26)\end{array}$ & $\begin{array}{c}-0.18 \\
(0.23)\end{array}$ \\
\hline \% of housing units built since 1990 & $\begin{array}{r}-0.05 \dagger \\
(0.01)\end{array}$ & $\begin{array}{r}-0.06 \dagger \\
(0.02)\end{array}$ \\
\hline Annexation since 1990 (none=ref) & $\begin{array}{r}1.87 \dagger \\
(0.34)\end{array}$ & $\begin{array}{c}0.44 \\
(0.68)\end{array}$ \\
\hline \multicolumn{3}{|c|}{ Functional specialization, 2010 (none=ref.) } \\
\hline Retirement & $\begin{array}{r}2.38 \dagger \\
(0.70)\end{array}$ & $\begin{array}{c}1.28 \\
(0.81)\end{array}$ \\
\hline Manufacturing & $\begin{array}{c}0.20 \\
(0.38)\end{array}$ & $\begin{array}{c}-0.59 \\
(0.52)\end{array}$ \\
\hline
\end{tabular}

(Continued on next page) 


\begin{tabular}{lcc}
\hline & Metro & Nonmetro \\
\hline Government & $-4.35 \dagger$ & $-3.13 \dagger$ \\
& $(0.69)$ & $(1.03)$ \\
Military & $-5.85 \dagger$ & $-8.39 \dagger$ \\
& $(0.75)$ & $(1.59)$ \\
School & $-1.79 \dagger$ & $-7.77 \dagger$ \\
& $(0.40)$ & $(0.78)$ \\
Central/principal city $(=1)$ & $3.10 \dagger$ & $1.87 *$ \\
& $(0.59)$ & $(0.82)$ \\
Level 2 controls & & $-2.72 \dagger$ \\
Total population, 2010 (ln) & -0.08 & $(0.42)$ \\
& $(0.31)$ & \\
Racial composition, 2010 & & $0.04 *$ \\
Percent black & 0.03 & $(0.02)$ \\
& $(0.04)$ & $0.15 \dagger$ \\
Percent hispanic & $0.08 \dagger$ & 0.03 \\
& $(0.03)$ & $-1.58 \dagger$ \\
Percent asian & $-0.21 *$ & $(0.42)$ \\
& $(0.10)$ & $0.51 \dagger$ \\
Political fragmentation & $2.67 \dagger$ & $(0.15)$ \\
Region (south as ref.) & $(0.76)$ & -1.01 \\
Northeast & & $(1.13)$ \\
& -0.86 & $4.532 \dagger$ \\
Midwest & $(0.94)$ & $(0.79)$ \\
West & 0.69 & $5.38 \dagger$ \\
Random effects & $(0.86)$ & 1.08 \\
Model residual variance & -0.62 & $(1.59)$ \\
\hline & $(1.08)$ & $(0.78)$ \\
\hline
\end{tabular}

Two-sided tests: $* p<.05 ;+p<.01$. 
level of level two variance explained by the metro (85.4 percent) and nonmetro (83.9 percent) models (Table 5). The model statistics also indicate more variability between nonmetro areas than between metro areas, as shown by the level of unconditional variance (105.1 in nonmetro areas versus 87.2 in metro areas).

As a final exercise (reported in Table 6), we replicate these HLM models and replace the diversity typology with a single summary measure of diversity, $E$. In general, the results provide additional support for the buffering hypothesis. Indeed, some preliminary analysis (not shown) revealed the effect of $E$ (without controls) on black-white segregation for metro places to be 0.43 . The HLM estimate reported in Table 6 is lower $(-0.33)$ but remains statistically significant at the 0.001 level. For nonmetro places, our estimates are 0.42 without controls (not shown) and and -0.31 with controls. The multivariate analyses reveal that more diversity is consistently associated with less black-white segregation. They do not reveal the specific demographic processes that contribute to this statistical association, an issue we address below.

To summarize our results, the total variance explained by the HLM models in Tables 5 and 6 can be decomposed into the within-metro (nonmetro) area (to account for place-to-place environment differences) and between-metro (nonmetro) area components (see Table 7). This analysis deals directly with the question of whether places matter in determining patterns of black-white residential segregation. The intra-class correlation coefficient (ICC) for the intercept-only model clearly indicates that places play a critical role in explaining variation in black-white residential segregation within and between metro and nonmetro areas. Approximately 30 percent of the variation in black-white segregation is due to differences between metro areas, leaving substantial variation explained by place differences within metropolitan areas. Clearly, this suggests that place matters in shaping patterns of black-white residential segregation in metropolitan areas. For nonmetro areas, the between variance component is even higher- 40 percent-suggesting that, in nonmetro areas, place plays a smaller role than in metro areas. Clearly variation in black-white residential segregation is embedded in broader regional spatial relations.

The summary results in Table 7 also show that the 15-category racial typology has considerably more explanatory power than the alternative summary indicator of racial and ethnic diversity $(E)$ in explaining variation in black-white segregation across metro (nonmetro) area (level two variance). For example, in metro areas, our comparison of the level two variance components across model specifications reveals that 72.8 percent $((87.25-23.71) / 87.25=0.728)$ of the between-metro area variation in black-white residential segregation was accounted for by differences in racial diversity, as measured by the 15-category typology. Substituting $E$, the comparable figure is $((87.25-46.27) / 87.25=0.470)$, or only 47.0 percent. The 15 category diversity typology also has more predictive power than $E$ in nonmetro areas (65.1 percent versus 32.4). 
Table 6: Fixed and Random Effects from HLM Regressions of 2010 Black-White Residential Segregation on Place Entropy and Other Place and Contextual Characteristics

\begin{tabular}{|c|c|c|}
\hline & Metro & Nonmetro \\
\hline Intercept & $\begin{array}{l}58.88 \dagger \\
(0.77)\end{array}$ & $\begin{array}{l}70.52 \dagger \\
(0.90)\end{array}$ \\
\hline Entropy index (E), 2010 & $\begin{array}{r}-0.33 \dagger \\
(0.01)\end{array}$ & $\begin{array}{r}-0.31 \dagger \\
(0.02)\end{array}$ \\
\hline \multicolumn{3}{|l|}{ Place controls } \\
\hline Total population, $2010(\ln )$ & $\begin{array}{r}-1.13 \dagger \\
(0.17)\end{array}$ & $\begin{array}{r}-2.43 \dagger \\
(0.42)\end{array}$ \\
\hline \multicolumn{3}{|l|}{ Economic characteristics } \\
\hline B-W median income ratio, 2010 & $\begin{array}{r}-1.44 \dagger \\
(0.27)\end{array}$ & $\begin{array}{c}-0.20 \\
(0.24)\end{array}$ \\
\hline$\%$ of housing units built since 1990 & $\begin{array}{r}-0.06 \dagger \\
(0.01)\end{array}$ & $\begin{array}{r}-0.06 \dagger \\
(0.02)\end{array}$ \\
\hline Annexation since 1990 (none=ref) & $\begin{array}{r}1.78 \dagger \\
(0.35)\end{array}$ & $\begin{array}{c}1.23 \\
(0.72)\end{array}$ \\
\hline \multicolumn{3}{|c|}{ Functional specialization, 2010 (none $=$ ref.) } \\
\hline Retirement & $\begin{array}{r}1.59 * \\
(0.73)\end{array}$ & $\begin{array}{l}1.37 \\
(0.87)\end{array}$ \\
\hline Manufacturing & $\begin{array}{r}1.20 \dagger \\
(0.40)\end{array}$ & $\begin{array}{c}-0.50 \\
(0.56)\end{array}$ \\
\hline Government & $\begin{array}{r}-4.24 \dagger \\
(0.73)\end{array}$ & $\begin{array}{r}-3.13 \dagger \\
(1.11)\end{array}$ \\
\hline Military & $\begin{array}{r}-6.40 \dagger \\
(0.78)\end{array}$ & $\begin{array}{r}-9.03 \dagger \\
(1.70)\end{array}$ \\
\hline School & $\begin{array}{r}-2.27 \dagger \\
(0.41)\end{array}$ & $\begin{array}{r}-9.72 \dagger \\
(0.83)\end{array}$ \\
\hline Central/principal city $(=1)$ & $\begin{array}{r}6.18 \dagger \\
(0.61)\end{array}$ & $\begin{array}{c}1.45 \\
(0.87)\end{array}$ \\
\hline \multicolumn{3}{|l|}{ Level 2 controls } \\
\hline Total population, $2010(\ln )$ & $\begin{array}{c}-0.35 \\
(0.37)\end{array}$ & $\begin{array}{r}-2.96 \dagger \\
(0.45)\end{array}$ \\
\hline \multicolumn{3}{|l|}{ Racial composition, 2010} \\
\hline Percent black & $\begin{array}{c}0.06 \\
(0.04)\end{array}$ & $\begin{array}{c}0.05 * \\
(0.02)\end{array}$ \\
\hline Percent hispanic & $\begin{array}{r}0.23 \dagger \\
(0.03)\end{array}$ & $\begin{array}{r}0.37 \dagger \\
(0.03)\end{array}$ \\
\hline Percent asian & $\begin{array}{c}-0.12 \\
(0.12)\end{array}$ & $\begin{array}{c}-0.64 \\
(0.45)\end{array}$ \\
\hline Political fragmentation & $\begin{array}{r}2.95 \dagger \\
(0.88)\end{array}$ & $\begin{array}{r}0.58 \dagger \\
(0.16)\end{array}$ \\
\hline \multicolumn{3}{|l|}{ Region (south as ref.) } \\
\hline Northeast & $\begin{array}{c}-1.12 \\
(1.11)\end{array}$ & $\begin{array}{c}1.99 \\
(1.21)\end{array}$ \\
\hline Midwest & 1.09 & $6.98 \dagger$ \\
\hline
\end{tabular}

(Continued on next page) 


\begin{tabular}{lcc}
\hline & Metro & Nonmetro \\
\hline \multicolumn{1}{c}{ West } & $(1.01)$ & $(0.85)$ \\
& $4.14 \dagger$ & $10.72 \dagger$ \\
Random effects & $(1.24)$ & $(1.07)$ \\
Unconditional variance & & \\
Model residual variance & 87.25 & 105.07 \\
\% of variance explained & 21.47 & 21.97 \\
\hline
\end{tabular}

Two-sided tests: $* p<.05 ;+p<.01$.

Table 7: Fit Statistics from Models of Place Black-White Residential Segregation, 2010

\begin{tabular}{|c|c|c|c|c|c|c|c|c|}
\hline & \multicolumn{5}{|c|}{ Metro } & \multicolumn{3}{|c|}{ Nonmetro } \\
\hline & $\begin{array}{c}\text { Level- } \\
\text { Two } \\
\text { Variance }\end{array}$ & ICC & Intercept & AIC & $\begin{array}{c}\text { Level- } \\
\text { Two } \\
\text { Variance }\end{array}$ & ICC & Intercept & AIC \\
\hline $\begin{array}{l}\text { Intercept- } \\
\text { only }\end{array}$ & & & & & & & & \\
\hline Model & 87.25 & 0.298 & 65.10 & 68313.0 & 105.07 & 0.410 & 77.50 & 29404.2 \\
\hline Typology & 23.71 & 0.146 & 52.56 & 64800.8 & 36.64 & 0.264 & 62.89 & 27472.6 \\
\hline Typology+ & & & & & & & & \\
\hline Controls & 14.93 & 0.106 & 51.99 & 51576.0 & 29.14 & 0.234 & 64.55 & 17106.9 \\
\hline $\begin{array}{c}\text { Typology+ } \\
\text { Controls } \\
\text { +Level2 } \\
\text { variables }\end{array}$ & 12.72 & 0.092 & 51.83 & 51314.8 & 16.93 & 0.156 & 63.29 & 16636.1 \\
\hline $\begin{array}{l}\text { E index } \\
\text { E index }+\end{array}$ & 46.27 & 0.232 & 63.93 & 65776.6 & 71.02 & 0.375 & 78.13 & 28420.8 \\
\hline $\begin{array}{c}\text { Controls } \\
\text { E index+ } \\
\text { Controls } \\
\text { +Level2 } \\
\text { variables }\end{array}$ & 33.60 & 0.199 & 60.14 & 52149.7 & 54.69 & 0.330 & 75.49 & 17722.0 \\
\hline
\end{tabular}


Differences in place racial diversity clearly matter for black-white residential segregation, as do other differences in place and regional (i.e., metro or nonmetro) characteristics. Restricting our discussion to the HLM models reported in Table 5 (using the racial typology), other metro place (level one) characteristics explained 37.0 percent $((23.708-14.931) / 23.708=0.370)$ of the remaining variance, while metro area (level two) characteristics explained 14.9 percent $((14.931-12.717) / 14.931=0.149)$ of the remaining variance. The comparable figures in nonmetro settings were 20.5 percent $((36.64-33.29 .14) / 36.64=0.205)$ and 41.9 percent $(29.14-16.93 / 29.14=0.419)$, respectively. Variation in black-white residential segregation reflects differences in racial composition, as well as other place and regional characteristics.

\section{Changes in Diversity and Segregation, 1990-2010}

The cross-sectional association between spatial diversity and black-white segregation may or may not reflect ongoing demographic processes over the study period. Consequently, Table 8 summarizes the HLM regression results but focuses on changes in diversity and segregation over the 1990-2010 period, net of other place and metro (nonmetro) characteristics. The dependent variable in these models is the percent change in $D$ between 1990 and 2010.

The estimates in Table 8 contrast places that became more racially diverse with those that became less diverse, remained stable, or shifted in racial composition while maintaining their level of diversity (e.g., WBH to WBA). The intercept of this model reveals that black-white segregation declined by 19.9 points between 1990 and 2010 for metro places that became more racially diverse. This decline greatly exceeds declines in black-white segregation observed in other metro places, especially those that experienced declines in diversity during the period $(b=5.38)$. For nonmetro places, changes in diversity over the study period were significantly but less strongly linked to growing diversity $(b=3.53)$. As places became more diverse, they also became less segregated.

General support for the buffering hypothesis is reinforced in models that include 1990-2010 change in $E$ as an alternative measure of diversity. These analyses show that the increases in $E$ between 1990 and 2010 (which indicate more diversity) are negatively associated with growth in black-white segregation in metro places, net of other place and metro (nonmetro) characteristics. However, reaching parity in the presence of racial and ethnic groups has no significant bearing on growth or decline in segregation in nonmetro areas. ${ }^{4}$

\section{A Coda on White Population Decline and Black-White Segregation}

Our empirical results provide general support for the buffering hypothesis; racial diversity is associated with less black-white segregation under many different model specifications. If racial residential integration is a public policy goal, such results provide optimism about the future, especially as the United States becomes a majority-minority country by 2043 (U.S. Census Bureau 2012). The results also suggest that black exceptionalism may be waning as the country diversifies. At the same time, our analyses have not identified possible demographic mechanisms responsible for the diversity-segregation association. A positive interpretation about 
Table 8: Fixed and Random Effects from HLM Regressions of Percent Change in B-W Segregation (D) on Place Transition, Net of Place and Metro(Nonmetro) Factors, 1990-2010

\begin{tabular}{|c|c|c|}
\hline & \multicolumn{2}{|c|}{ Change in place typology since 1990} \\
\hline & Metro & Nonmetro \\
\hline Intercept & $\begin{array}{r}-19.94^{\dagger} \\
(0.88)\end{array}$ & $\begin{array}{r}-16.51^{\dagger} \\
(1.13)\end{array}$ \\
\hline \multicolumn{3}{|l|}{ 1990-2010 Place transition (gain diversity as ref.) } \\
\hline Lose diversity & $\begin{array}{c}5.38^{\dagger} \\
(0.84)\end{array}$ & $\begin{array}{r}3.53^{\dagger} \\
(1.09)\end{array}$ \\
\hline No diversity change & $\begin{array}{r}2.69^{+} \\
(0.56)\end{array}$ & $\begin{array}{c}0.64 \\
(0.67)\end{array}$ \\
\hline Shift composition & $\begin{array}{r}5.98^{\dagger} \\
(1.39)\end{array}$ & $\begin{array}{c}0.32 \\
(1.42)\end{array}$ \\
\hline \multicolumn{3}{|l|}{ Random effects } \\
\hline Unconditional variance & 31.16 & 21.08 \\
\hline Model residual variance & 8.64 & 11.35 \\
\hline \multirow[t]{3}{*}{$\%$ of variance explained } & 72.27 & 46.16 \\
\hline & \multicolumn{2}{|c|}{ Change in entropy index since 1990} \\
\hline & Metro & Nonmetro \\
\hline Intercept & $\begin{array}{r}-18.45^{\dagger} \\
(0.87)\end{array}$ & $\begin{array}{r}-15.28^{+} \\
(1.15)\end{array}$ \\
\hline Entropy index (E) percent change since 1990 & $\begin{array}{r}-0.01^{+} \\
(0.01)\end{array}$ & $\begin{array}{c}0.01 \\
(0.01)\end{array}$ \\
\hline Random effects & & \\
\hline Unconditional variance & 31.16 & 21.08 \\
\hline Model residual variance & 10.76 & 12.81 \\
\hline$\%$ of variance explained & 65.47 & 39.23 \\
\hline
\end{tabular}

$* p<0.05 ;+p<0.01$.

Notes: The following place-level factors were included as controls: 1990 black-white D, 1990 total population and demographic composition, black less white and other minority less white growth rate since 1990, change in black-white median income ratio since 1990, housing unit construction and annexation since 1990, 1990 functional specialization, and central/principal city status. The 1990 total population and demographic composition of the metro (nonmetro) context, political fragmentation, and the regional location of the metro (nonmetro) context were also included.

racial inclusion, based on empirical evidence supporting the buffering hypothesis, requires some caveats, especially if growing black-white diversity and declining segregation result from white depopulation in U.S. cities, suburbs, and small towns.

Here, we evaluate changes in the size of the white and black populations for different types of places, regardless of metro or nonmetro status. We examine a constant set of places over time using diversity classifications that are fixed either at the end of the study period (2010) or at the beginning of the study period (1990). 
For places with a fixed designation at the end of the period, we show changes in the black and white populations regardless of their classification in the earlier period. For places with a fixed designation at the beginning of the period, we show changes in the black and white populations regardless of their classification in the later period. In this way, we are able to report demographic changes in the same places over time, regardless of shifts in racial classification.

In Table 9, we show, for example, that the non-Hispanic white population declined absolutely over the 1990-2010 period (-0.3 percent), even as the population overall increased rapidly (23.6 percent). For some of the most diverse places in 2010, the white population declined very rapidly over the preceding 20-year period. For example, the white population declined by a whopping 55.6 percent in allminority communities (BHA), 63.6 percent in $\mathrm{BH}$ communities, 66.7 percent in BA communities, and 75.2 percent in black communities. Like Detroit, Baltimore, and other majority-minority places, the United States is witnessing large absolute declines in its white populations in places with large black populations, even as overall diversity has increased.

Significantly, the only types of places (in 2010) with 1990-2010 increases in the white population were white-presence communities: WHA (10.6 percent), WA (8.5 percent), and $\mathrm{W}$ (6.3 percent). Over the same period, the white population overall declined in places with a black presence: -4.5 percent in WB communities, -8.4 percent in $\mathrm{BH}$ communities, and -18.1 percent in $\mathrm{B}$ communities. More racial diversity has ushered in lower segregation, but ongoing population changes among blacks and whites suggest the need for caution before giving an entirely optimistic interpretation to current black-white segregation patterns. Whites are seemingly hunkering down in some white places, which, as we have shown, are highly segregated. These results again highlight black exceptionalism, as indicated by where the white population is declining (i.e., in communities with a B) and where it is growing (i.e., in communities without a B). The results may also suggest an emerging pattern of "white exceptionalism," potentially indicated by the growing place-to-place isolation of whites.

Our cautionary interpretation of the empirical evidence is also warranted by our parallel analyses that linked types of places in 1990 to subsequent white and black population change (Table 8). Here, the most diverse communities (WBHA) in 1990 lost 11.2 percent of their white populations, while their black populations increased 19.1 percent between 1990 and 2010. Among the largest losers of white population were all-minority communities (BHA), which lost almost half (49.7 percent) of their white population after 1990. BH, BA, HA, and B communities also lost large shares of their white populations $(-21.7,-66.7,-50.0$, and -51.8 percent, respectively). These figures contrast vividly with all-white communities in 1990, which experienced increases in white population over following 20 years (13.2 percent), as did WHA communities (9.2 percent). These data suggest a pattern of black avoidance, both in places where whites experience declines in population size and in places where white populations are growing. Growing diversity and declining black-white segregation are occurring hand in hand with white population declines in neighborhoods (as reported in previous neighborhood studies) and disproportionately minority communities (as shown here). 


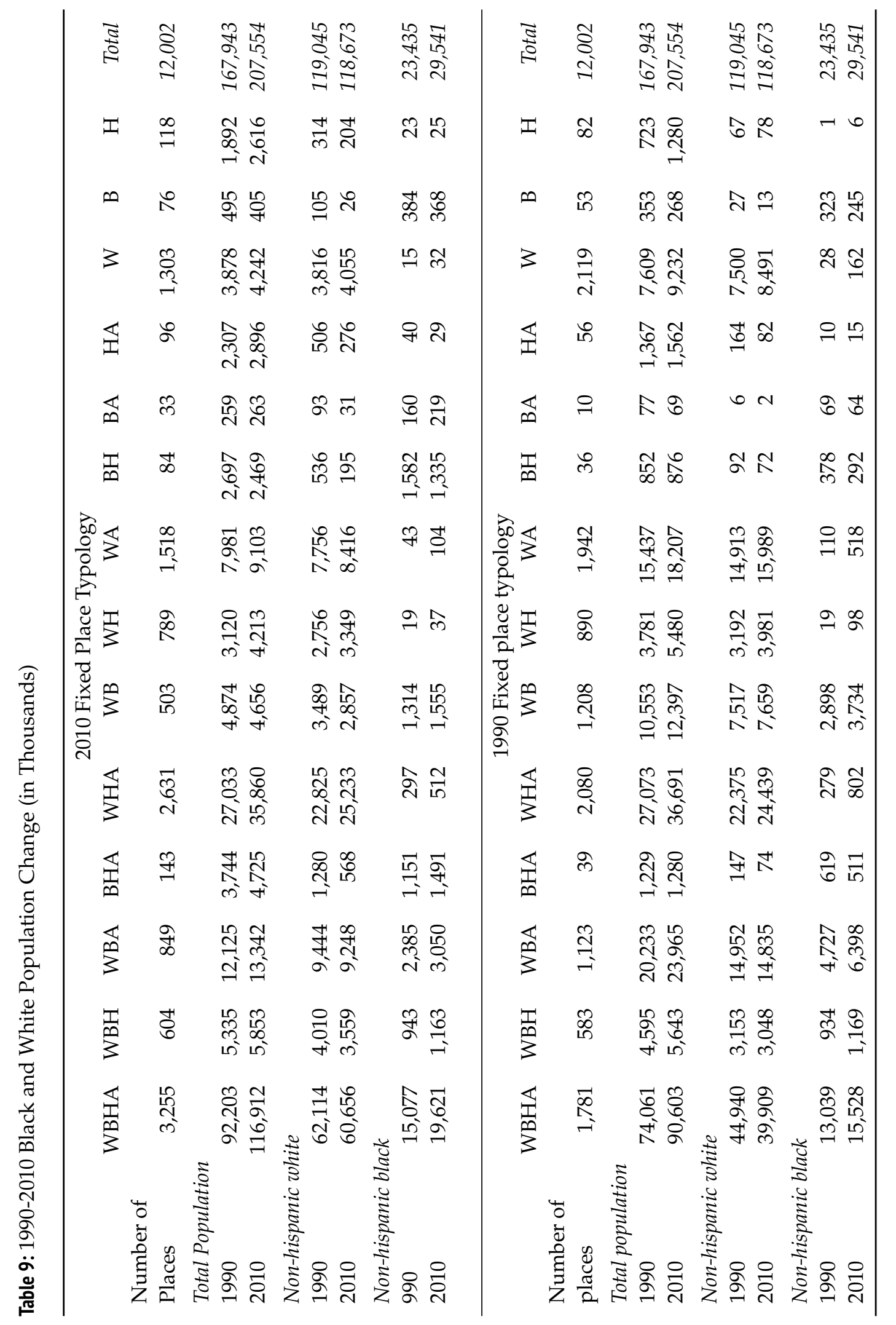




\section{Discussion and Conclusion}

The so-called buffering hypothesis suggests that growing diversity in the United States will pay a demographic dividend in the form of declining black-white segregation-a blurring of the U.S. color line. A key feature of our study is its inclusion of all U.S. places, not just metro central cities or multi-county metro regions. Our comprehensive place-based approach arguably is more appropriate than ever, especially at a time of extraordinary growth in the number of majority-minority communities, white depopulation in big cities, and expansion of U.S. minority populations to suburban communities and new immigrant destinations outside traditional metro gateway cities (Lichter 2012; 2013). Our block- and place-based approach to the study of racial segregation is framed by the apparently growing political fragmentation of metro and nonmetro areas, where legal and administrative machinery are sometimes used to establish land use regulations, zoning ordinances, and annexation that effectively exclude historically disadvantaged minority populations.

Our study provides perhaps the most exhaustive and up-to-date empirical evidence that growing racial and ethnic diversity is associated with declines in blackwhite segregation. In this respect, our results are consistent with commonplace interpretations from previous studies by Frey and Farley (1996) and Iceland (2004), as well as speculation that growing diversity is leading to a new post-racial future, where race matters less in our daily lives (Lee and Bean 2010). In fact, our analysis shows that some of the largest declines in black-white segregation occurred in the places that were the most diverse racially or that had experienced the most significant increases in diversity over the 1990-2010 period, as measured with an adapted diversity typology based on Logan and Zhang (2010) and with the entropy score. Taken at face value, our empirical results suggest that growing racial and ethnic diversity in the United States, which has been played out at the community and neighborhood levels, may have the salutary effect of "dimming" persistently bright racial boundaries between blacks and whites.

Yet as we have emphasized throughout our analyses, any statistical association between diversity and segregation has alternative interpretations that counsel caution against unequivocal optimism about the racial future of the United States. For starters, the U.S. black population in 2010 remains highly segregated from whites; the so-called "end of the segregated century" has not brought an end to black-white segregation. The average black person lives in a community that has a segregation index of 62.3 (metro) and 62.6 (nonmetro); Massey and Denton (1993) have labeled segregation (D) at levels above 60 as high. Moreover, our results show that growing racial diversity is associated with white depopulation, as well as disproportionate white population increases in the least diverse or mostly white places. Whites also remain heavily concentrated in communities and areas outside the places included in this study. In 2010, whites composed 86 percent of the population in areas outside of the 12,002 places included in this study. This percentage far exceeds the white proportion of the U.S. population (63 percent) and the white proportion in the places studied here ( 57 percent). 
More generally, our results raise important theoretical questions about the buffering hypothesis itself and its main assumptions, including the commonplace view that the growth of diverse populations promotes intergroup contact and (by extension) positive relations between blacks and whites. The demographic paradox is that diversity is growing in tandem with reductions in black-white segregation, even as whites depopulate in large numbers from the most diverse communities. Our findings are seemingly consistent with other studies showing highly selective white out-movement (see Crowder, Pais, and South 2012). Although additional study is required to determine the exact mechanism, whites who "stay behind" may: 1) be more open to residence in integrated areas; 2) have not had enough time to flee (but will); or 3) be influenced by some other micro-level process to stay in diversifying areas (e.g., are trapped by a depressed housing market), while other whites leave for homogeneous communities or neighborhoods elsewhere. Our results may in fact suggest an emerging pattern of white spatial and cultural isolation from the United States' new multiracial, multiethnic mainstream.

Can salutary interpretations of race relations be assigned to evidence of declining big city black-white segregation when, as we have shown here, whites are depopulating in the Unied States' most diverse places? Previous studies of neighborhood racial change have shown temporary shifts to integrated neighborhoods before whites eventually leave for less diverse neighborhoods (i.e., a process of invasion and succession). The buffering hypothesis seemingly rests on the assumption that whites are retained in diversifying neighborhoods (Logan and Zhang 2011), but we have shown that diverse communities are often in transition. Short of racial stability, the statistical relationship between diversity and black-white segregation should not distract us from ongoing processes of white flight and population decline in diverse contexts.

Our results also have potentially important implications for future settlement patterns as the United States transitions to a majority-minority country and as new global communities emerge (Lichter 2013; U.S. Census Bureau 2012). For example, cross-sectional snapshots sometimes hide communities in racial transition. Any optimism about the United States' post-racial future or about the country's increasingly diverse places-global communities or neighborhoods-must acknowledge their racial instability as they transition from one kind of place to another (Friedman 2008). Looking back 20 years, additional analysis (not shown) reveals that only 26.9 percent of communities that were black-white (using our typology) in 1990 were still black-white communities in 2010. This analysis also shows that the majority (62 percent) of black-white places had become multiethnic/multiracial places in the same period (309 became WBHA, 202 became WBH, and 238 became WBA). In the end, our analysis paints a rather complicated picture of recent patterns of spatial diversity and segregation, a picture that illustrates the difficulty in successfully forecasting the racial future of the United States and, more importantly, its racial boundaries.

Our study is not without some limitations. For example, we have emphasized changing black-white segregation, largely because of its exceptionally high levels historically and because the buffering hypothesis has typically been applied to blacks rather than other minority populations, such as Hispanics and Asians. In 
the future, it will be increasingly important to map the demographic responses of nonblack-nonwhite minorities to the shifting size, distribution, and composition of America's black population (Tienda and Fuentes 2014). Moreover, our results have highlighted white reactions-self-segregation - to diversity in general and to blacks in particular. For both theoretical and methodological reasons, it is imperative for future studies to focus more explicitly on diversity and segregation between whites and nonblack-nonwhite minorities and among nonblack-nonwhite minorities themselves. This approach will be especially important during a period of segmented assimilation (Portes and Zhou 1993), where some nonblack-nonwhite minorities seemingly are moving toward the white end of the white-black racial continuum, others languish in place or join a black underclass, and yet others successfully maintain their own ethnic identity rather than identify as white. Clearly, broad racial and ethnic categories hide tremendous heterogeneity in the rapidly growing nonblack-nonwhite population of Asians and Hispanics (Tienda and Fuentes 2014).

In the end, our analysis provides an empirical benchmark for additional study rather than final answers. It raises unanswered questions about the possible demographic and social mechanisms that link growing diversity to declining residential segregation in the United States. There nevertheless can be little doubt that growing diversity and continuing high rates of black-white segregation (perhaps at different spatial scale) are unlikely to be reversed anytime soon. Traditional or conventional studies of racial and ethnic residential segregation-those focused on big city neighborhoods alone-provide an important but perhaps increasingly incomplete picture of recent patterns of racial segregation. Diversity and segregation are unfolding unevenly across U.S. regions, cities, suburbs, and small towns. Our study makes the case for a spatially inclusive perspective that directly acknowledges this empirical fact.

\section{Notes}

1 For 2010, this means that 59 percent of blacks must move to other neighborhoods (i.e., to disproportionately white census tracts) in order to achieve equality in the percentage distribution of blacks and whites across all neighborhoods.

2 We evaluated whether our analyses are sensitive to different selection criteria. We replicated the analyses with a sample that included all places in each census (e.g., new developments or incorporated places that emerged during each decade, as well as the few places that "died" during the 1990-2010 period). In the end, these additional sensitivity analyses, based on a slightly different (larger) sample of places, did not change our empirical results or substantive interpretations. These data are available upon request.

3 There were no A places.

4 The intra-class correlation coefficient (ICC) shows that 7.4 percent in the change in black-white residential segregation is accounted for by the metro context. This clearly indicates that the metro context has a smaller effect than the place context on changes in black-white residential segregation. Diversity also plays a greater role when groups reach a similar level of presence compared to having a simple presence of groups, or experiencing compositional change. The Eindex explains 31.22 percent of metro differences $((31.16-21.43 / 31.16=0.312)$. In contrast, the typology and racial composition explain 11.87 and 3.90 percent, respectively. 


\section{References}

Alba, Richard D. 2009. Blurring the Color Line: The New Chance for a More Integrated America. Cambridge, MA: Harvard University Press.

Alba, Richard D., Nancy A. Denton, Shu-yin J. Leung, and John R. Logan. 1995. “Neighborhood Change under Conditions of Mass Immigration: The New York City Region, 19701990." International Migration Review 29:625-56. http://dx . doi . org/10 . 2307/2547497.

Allport, Gordon W. 1954. The Nature of Prejudice. Reading, MA: Addison-Wesley.

Crowder, Kyle, Jeremy Pais, and Scott J. South. 2012. "Neighborhood Diversity, Metropolitan Constraints, and Household Migration." American Sociological Review 77:325-53. http: //dx.doi.org/10.1177/0003122412441791.

Denton, Nancy A. and Douglas S. Massey. 1991. "Patterns of Neighborhood Transition in a Multiethnic World: U.S. Metropolitan Areas, 1970-1980." Demography 28:41-63. http://dx.doi.org/10.2307/2061335.

Du Bois, W.E.B. 1997 [1903]. The Souls of Black Folk. Boston: Bedford Books.

Economic Research Service. 2013. County Typology Codes. http://www.ers.usda.gov/ data-products/county-typology-codes . aspx.

Farley, Reynolds and William H. Frey. 1994. "Changes in the Segregation of Whites from Blacks during the 1980s: Small Steps Toward a More Integrated Society." American Sociological Review 59:23-45. http://dx.doi.org/10.2307/2096131.

Farrell, Chad R. 2008. “Bifurcation, Fragmentation, or Integration? The Racial and Geographic Structure of U.S. Metropolitan Segregation, 1990-2000." Urban Studies 45:467-99. http://dx.doi.org/10.1177/0042098007087332.

Farrell, Chad R. and Barrett A. Lee. 2011. "Racial Diversity and Change in Metropolitan Neighborhoods." Social Science Research 40:1108-23. http://dx.doi.org/10.1016/j . ssresearch.2011.04.003.

Fischer, Claude S., Gretchen Stockmayer, Jon Stiles, and Michael Hout. 2004. “Distinguishing the Geographic Levels and Social Dimensions of U.S. Metropolitan Segregation, 1960 2000." Demography 41:37-59. http://dx.doi .org/10.1353/dem.2004.0002.

Frey, William H. and Reynolds Farley. 1996. "Latino, Asian, and Black Segregation in U.S. Metropolitan Areas: Are Multi-Ethnic Metros Different?" Demography 33:35-50. http://dx.doi.org/10.2307/2061712.

Friedman, Samantha. 2008. “Do Declines in Residential Segregation Mean Stable Neighborhood Racial Integration in Metropolitan America? A Research Note." Social Science Research 37:920-33. http://dx.doi.org/10.1016/j.ssresearch.2007.06.010.

Gans, Herbert J. 1999. "The Possibility of a New Racial Hierarchy in the Twenty-First-Century United States." Pp. 371-90 in The Cultural Territories of Race: Black and White Boundaries, edited by Michéle Lamont. Chicago: University of Chicago Press.

Glaeser, Edward and Jacob Vigdor. 2012. The End of the Segregated Century: Racial Separation in America's Neighborhoods, 1990-2010. Civic Report 66. New York: Manhattan Institute.

Hall, Matthew and Barrett Lee. 2010. “How Diverse are US Suburbs?” Urban Studies 47:3-28. http://dx.doi.org/10.1177/0042098009346862.

Holloway, Steven R., Richard Wright, and Mark Ellis. 2012. “The Racially Fragmented City? Neighborhood Racial Segregation and Diversity Jointly Considered." Professional Geographer 64:63-82. http://dx.doi.org/10.1080/00330124.2011.585080. 
Iceland, John. 2004. "Beyond Black and White: Metropolitan Residential Segregation in Multi-Ethnic America." Social Science Research 33:248-71. http://dx.doi .org/10.1016/ S0049-089X (03) 00056-5.

Iceland, John and Melissa Scopilliti. 2008. "Immigrant Residential Segregation in U.S. Metropolitan Areas, 1990-2000." Demography 45:79-94. http://dx. doi .org/10.1353/ dem.2008.0009.

Iceland, John, Gregory Sharp, and Jeffrey M. Timberlake. 2013. "Sun Belt Rising: Regional Population Change and the Decline in Black Residential Segregation, 1970-2009." Demography 50:97-123. http://dx.doi .org/10.1007/s13524-012-0136-6.

Johnson, Kenneth M. and Daniel T. Lichter. 2008. “Natural Increase: A New Source of Population Growth in Emerging Hispanic Destinations." Population and Development Review 34:327-46. http://dx . doi . org/10.1111/j.1728-4457.2008.00222.x.

Johnson, Kenneth M. and Daniel T. Lichter. 2010. “Growing Diversity among America's Children and Youth: Spatial and Temporal Dimensions." Population and Development Review 36:151-75. http://dx.doi.org/10.1111/j.1728-4457.2010.00322.x.

Kim, Ann H. and Michael J. White. 2010. “Panethnicity, Ethnic Diversity, and Residential Segregation." American Journal of Sociology 115:1158-96. http://dx . doi .org/10.1086/ 651375.

Lee, Barrett A., Sean F. Reardon, Glenn Firebaugh, Chad R. Farrell, Stephen A Matthews, and David O'Sullivan. 2008. "Beyond the Census Tract: Patterns and Determinants of Racial Segregation at Multiple Geographic Scales." American Sociological Review 73:766-91. http://dx.doi.org/10.1177/000312240807300504.

Lee, Barrett A., John Iceland, and Chad R. Farrell. 2014. "Is ethnoracial residential integration on the rise? Evidence from metropolitan and micropolitan America since 1980." Pp 415-56 in Diversity and disparities: America enters a new century, edited by John Logan. New York: Russell Sage Foundation.

Lee, Jennifer and Frank D. Bean. 2010. The Diversity Paradox: Immigration and the Color Line in 21st Century America. New York: Russell Sage Foundation.

Lichter, Daniel T. 2012. "Immigration and the New Racial Diversity in Rural America." Rural Sociology 77:3-35. http://dx.doi.org/10.1111/j.1549-0831.2012.00070.x.

Lichter, Daniel T. 2013. "Integration or Fragmentation? Racial Diversity and the American Future." Demography 50:359-391. http://dx.doi.org/10.1007/s13524-013-0197-1.

Lichter, Daniel T., Domenico Parisi, and Michael C. Taquino. 2012. "The Geography of Exclusion: Race, Segregation, and Concentrated Poverty." Social Problems 59:364-88. http://dx.doi.org/10.1525/sp.2012.59.3.364.

Lichter, Daniel T., Domenico Parisi, Steven Michael Grice, and Michael C. Taquino. 2007. "National Estimates of Racial Segregation in Rural and Small-Town America." Demography 44:563-81. http://dx.doi.org/10.1353/dem.2007.0030.

Lichter, Daniel T., Domenico Parisi, Michael C. Taquino, and Steven Michael Grice. 2010. "Residential Segregation in New Hispanic Destinations: Cities, Suburbs, and Rural Communities Compared." Social Science Research 39:215-30. http://dx.doi .org/10.1016/j . ssresearch.2009.08.006.

Logan, John R., B.J. Stults and Reynolds Farley. 2004. "Segregation of Minorities in the Metropolis: Two Decades of Change." Demography 41:1-22. http://dx.doi.org/10. 1353/dem.2004.0007.

Logan, John R. and Charles Zhang. 2010. “Global Neighborhoods: New Pathways to Diversity and Separation." American Journal of Sociology 115:1069-1109. http://dx. doi . org/10.1086/649498. 
Massey, Douglas S. and Nancy A. Denton. 1993. American Apartheid: Segregation and the Making of the Underclass. Cambridge, MA: Harvard University Press.

Massey, Douglas S., Jonathan Rothwell, and Thurston Domina. 2009. "The Changing Bases of Segregation in the United States." Annals of the American Academy of Political and Social Science 626:74-90. http://dx.doi .org/10.1177/0002716209343558.

Oliver, J. Eric and Janelle Wong. 2003. "Intergroup Prejudice in Multiethnic Settings." American Journal of Political Science 47:567-82. http://dx . doi .org/10. 2307/3186119.

Östh, John, William A.V. Clark, and Bo Malmberg. 2015. "Measuring the Scale of Segregation Using K-Nearest Neighbor Aggregates." Geographical Analysis 47: 34-49. http://dx . doi . org/10.1111/gean.12053.

Parrado, Emilio A. 2011. "How High is Hispanic/Mexican Fertility in the U.S.? Immigration and Tempo Considerations." Demography 48:1059-80. http://dx.doi.org/10.1007/ s13524-011-0045-0.

Parisi, Domenico, Daniel T. Lichter, and Michael C. Taquino. 2011. “Multi-Scale Residential Segregation: Black Exceptionalism and America's Changing Color Line." Social Forces 89:829-52. http://dx.doi.org/10.1353/sof .2011.0013.

Putnam, Robert D. 2007. "E Pluribus Unum: Diversity and Community in the TwentyFirst Century." Scandinavian Political Studies 30:137-74. http://dx. doi .org/10.1111/j . $1467-9477.2007 .00176 . x$.

Reardon, Sean F., Stephen A. Matthews, David O'Sullivan, Barrett A. Lee, Glenn Firebaugh, Chad R. Farrell, and Kendra Bischoff. 2008. "The Geographic Scale of Metropolitan Segregation." Demography 45:489-514. http://dx.doi.org/10.1353/dem.0.0019.

Rugh, Jacob S. and Douglas S. Massey. 2010. "Racial Segregation and the American Foreclosure Crisis." American Sociological Review 75:629-51. http://dx.doi.org/10.1177/ 0003122410380868.

Sears, David O. and Victoria Savalei. 2006. “The Political Color Line in America: Many ‘Peoples of Color' or Black Exceptionalism?" Political Psychology 27:895-924. http: //dx.doi.org/10.1111/j.1467-9221.2006.00542.x.

South, Scott J., Kyle Crowder, and Jeremy Pais. 2011. “Metropolitan Structure and Neighborhood Attainment: Exploring Intermetropolitan Variation in Racial Residential Segregation." Demography 48:1263-92. http://dx. doi .org/10.1007/s13524-011-0062-z.

Taylor, Marylee C. 1998. "How White Attitudes Vary with the Racial Composition of Local Populations: Numbers Count." American Sociological Review 63:512-35. http://dx. doi . org/10.2307/2657265.

Tienda, Marta and Norma Fuentes. 2014. "Hispanics in Metropolitan America: New Realities and Old Debates." Annual Review of Sociology 40:499-520. http://dx.doi .org/10.1146/ annurev-soc-071913-043315.

U.S. Census Bureau. 2013. “Geographic Terms and Concepts - Places.” Retrieved March 11, 2013 http://www. census.gov/geo/reference/gtc/gtc_place.html\{\#\}cdp.

U.S. Census Bureau. 2012. “2012 National Population Projections.” Retrieved March 11, 2013 http://www. census .gov/population/projections/data/national/2012.html. 
Acknowledgements: The authors acknowledge the helpful comments or reactions of Robert L. Boyd, Reynolds Farley, Matt Hall, John Iceland, and John Logan, as well as the editors at Sociological Science. They also acknowledge research support from the National Strategic Planning \& Analysis Research Center (nSPARC) at Mississippi State University, the Cornell Population Center, and the Netherlands Interdisciplinary Demographic Institute.

Domenico Parisi: Department of Sociology, Mississippi State University.

E-mail: mimmo.parisi@nsparc.msstate.edu.

Daniel Lichter: Policy Analysis \& Management and Sociology, Cornell University. Email: dt128@cornell.edu

Michael C. Taquino: National Strategic Planning \& Analysis Research Center, Mississippi State University. E-mail: mtaquino@nsparc.msstate.edu 